\title{
Eksistensi Konsep Nilai “Luan dan Teben” sebagai Pembagian Ruang pada Level Makro Berdasarkan Nilai Tradisional Bali di Wilayah Selatan Kabupaten Badung
}

\author{
Ni Made Dwi Sulistia Budhiari ${ }^{1}$, Imam Buchori²
}

Diterima : 18 September 2014

Disetujui : 2 Oktober 2014

\begin{abstract}
Bali Province has had local wisdom values as conceptual in its territory construction. This conceptual value system is an elaboration applied comprehensively and systematically in every aspect construction. Value concept that animates those elements are inspired by values of culture and translated into a spatial form. Every concept each value has an area that characterize as intermediate (in the middle). This zone system generates region to be designated for certain types of activities, which aim to maintain the balance of macrocosmos and microcosmos. Nowadays, the development that occurred in Badung is under control, due to the existence of Bali as ODTW, resulting in high interest investment, which in turn gives a positive and negative impact. This issue is interesting to be a study, considering the utilization of space in the area of Bali should be attached with the concept of macro space division implied in the positive rule. Based on the analysis by making a comparison between the map overlay spatial through the value concept "local genius" of space distribution on a macro level in the South region of Badung, it can be seen that the existence of value concept has undergone a shift in area and there are not more types of designing which specialize as it has been determined as the value concept
\end{abstract}

Key words: local genius, space division on macro level (luan dan teben), land use

\begin{abstract}
ABSTRAK
Propinsi Bali telah memiliki nilai-nilai kearifan lokal sebagai konseptual dalam pembangunan wilayahnya. Tatanan nilai konseptual ini merupakan suatu elaborasi yang diterapkan secara komprehensif dan sistematis pada setiap aspek pembangunan. Konsep nilai yang menjiwai unsur-unsur tersebut dijiwai oleh nilai-nilai Budaya yang diterjemahkan ke dalam wujud keruangan. Setiap konsep nilai tersebut masing-masing nilai memiliki wilayah yang bersifat madya (tengah). Sistem perzoningan tersebut menghasilkan wilayah dengan peruntukkan untuk jenis kegiatan tertentu, yang bertujuan untuk menjaga keseimbangan makrokosmos dan mikrokosmos. Dewasa ini arah pembangunan yang terjadi di Kabupaten Badung dirasakan mulai tidak terkendali, hal ini dikarenakan eksistensi Bali sebagai ODTW, mengakibatkan tingginya minat berinvestasi yang pada akhirnya memberikan dampak positif dan negatif. Fenomena ini menarik dilakukan suatu kajian, mengingat dalam pemanfaatan ruang di wilayah Bali harus berdasarkan pada konsep pembagian ruang makro yang tersirat dalam aturan positif. Berdasarkan hasil analisa dengan melakukan perbandingan antara peta overlay pemanfaatan ruang terhadap konsep nilai "local genius" pembagian ruang pada level makro di wilayah Selatan Kabupaten Badung, maka dapat dilihat bahwa eksistensi dari konsep nilai tersebut telah mengalami pergeseran secara luasan dan tidak terdapat lagi jenis peruntukkan yang mengkhusus seperti yang telah ditentukan sesuai konsep nilai tersebut.
\end{abstract}

Kata kunci: konsep nilai, ruang makro, tradisional Bali

\footnotetext{
${ }^{1}$ Balai Pengembangan Teknologi Perumahan Tradisional Denpasar

2 Dosen Jurusan Perencanaan Wilayah dan Kota, Undip, Semarang, Jawa Tengah

Kontak Penulis : dwi_miracle@yahoo.com
} 


\section{PENDAHULUAN}

Local genius atau yang lebih dikenal dengan kearifan lokal merupakan suatu konsep hidup yang bertahan dan tetap tumbuh dalam perilaku tatanan kehidupan. Propinsi Bali merupakan salah satu propinsi yang menggunakan nilai kearifan lokal sebagai konseptual dalam pembangunan wilayahnya. Tatanan nilai konseptual ini merupakan suatu elaborasi yang diterapkan secara komprehensif dan sistematis pada setiap aspek yang berhubungan dengan pembangunan yang merupakan bagian dari kegiatan pemanfaatan ruang. Wawasan budaya menempatkan kebudayaan dalam tiga kategori fungsi dasar bagi pembangunan kota, yaitu sebagai potensi, sebagai pendekatan dan sebagai tujuan (Geriya dalam Salain, 2001). Tatanan nilai yang tumbuh di masyarakat merupakan budaya Bali yang dijiwai oleh agama Hindu. Agama Hindu sebagai jiwa kebudayaan Bali secara terpadu juga berperan sebagai, potensi, pendekatan dan tujuan pembangunan sektoral, lintas sektor, dan lintas bidang (Salain, 2001). Wujud penerapan tatanan nilai tersebut, juga dituangkan dalam penataan ruang di wilayah Propinsi Bali, yaitu pada tahapan perencanaan, pemanfaatan ruang dan pengendalian ruang.

Eksistensi Bali sebagai objek daya tarik wisatawan (ODTW) memberikan pengaruh yang besar terkait dengan perkembangan wilayah-wilayah kota di Propinsi Bali. Berdasarkan data BPS (Badung Dalam Angka, 2013) banyaknya usaha akomodasi di Kabupaten Badung dari tahun 2006-2012 mengalami peningkatan sebesar 2214 (dua ribu dua ratus empat belas) usaha akomodasi. Berkembangnya usaha akomodasi tersebut tentunya menyebabkan tingginya kebutuhan lahan.Melihat perkembangan yang demikan pesatnya, maka sesuai amanah Peraturan Daerah Propinsi Bali Nomor 16 Tahun 2009 tentang Rencana Tata Ruang Wilayah Propinsi Bali Tahun 2009-2029, Kabupaten Badung memiliki fungsi sebagai Pusat Kegiatan Nasional (PKN) yang sekaligus telah ditetapkan sebagai Kawasan Strategis Nasional (KSN), sehingga perlu dilakukan pengendalian perkembangan dalam pemanfaatan ruang terhadap kawasan tersebut. Memiliki fungsi yang demikian disebabkan oleh potensi Badung sebagai wilayah dengan topografi yang mudah dikembangkan sebagai ODTW. Perkembangan pembangunan yang tidak merata yang terjadi di Kabupaten Badung, dipengaruhi oleh aktivitas penduduknya. Bila dilihat berdasarkan kondisi di lapangan wilayah selatan Kabupaten Badung mengalami perkembangan pembangunan yang lebih pesat dan semakin ke utara semakin berkurang. Nilai lebih yang dimiliki oleh Badung memberikan nilai positif sekaligus akibat negatif. Nilai positif yang ditimbulkan tentu saja berkaitan dengan sektor perekonomian yang dalam hal ini adalah berkaitan dengan Pendapatan Asli Daerah (PAD) Kabupaten Badung, sedangkan nilai negatif yang diperoleh adalah tidak terkendalinya alih fungsi lahan dan juga dampak yang tidak terlihat secara langsung adalah berkaitan keberlanjutan nilai-nilai budaya, terkait dengan konsep nilai tradisional Bali dalam pemanfaatan ruang.

Berdasarkan perkembangan permasalahan yang dihadapi oleh Kabupaten Badung maka dilakukan penelitian terhadap nilai-nilai tradisional dikaitkan dengan kegiatan penataan ruang. Maka menarik dilakukan suatu kajian tentang bagaimanakah eksistensi konsep nilai pembagian ruang berdasarkan konsep Luan dan Teben yang merupakan konsep nilai pembagian ruang makro. Adapun wilayah yang dijadikan sebagai objek kajian adalah wilayah selatan dari Kabupaten Badung.

\section{METODE PENELITIAN}

Dalam penulisan penelitian ini menggunakan metode penelitian pendekatan positifivistik yang bersifat deduktif. Proses penelitian bersifat deduktif dimana untuk menjawab rumusan 
masalah digunakan konsep atau teori (Sugiyono, 2008). Berdasarkan pendekaan tersebut penelitian ini didasarkan pada fakta yang terjadi di lapangan yang kemudian dilakukan kajian berupa eksistensi terhadap penerapan konsep nilai pembagian ruang pada level makro, khususnya yang terjadi di wilayah studi penelitian yaitu wilayah selatan Kabupaten Badung.

\section{Teknik Pengumpulan Data dan Teknik Sampling}

Pengumpulan data dilakukan melalui sumbe data primer dan sumber data sekunder. Sumber data primer diperoleh melaui kuisioner, wawancara dan obeservasi sedangkan sumber data sekunder diperoleh melalui kajian literatur yang diperoleh dari intasi pemerintah. Teknik sampling yang digunakan dalam penelitian ini adalah teknik purposive sampling. Penggunaan teknik sampling ini merupakan metode sampling yang berdasarkan pada pertimbangan tertentu.

TABEL 1

REKAPITULASI JUMLAH RESPONDEN

\begin{tabular}{rrr}
\hline No & Responden & Jumlah \\
\hline $\mathbf{2}$ & Bappeda Kabupaten Badung & 18 \\
3 & Dinas Cipta Karya & 6 \\
4 & Akademisi, Budayawan, Pemuka Agama & 8 \\
& Total Responden & 20 \\
\hline
\end{tabular}

Sumber : Analisis Penulis, 2013

\section{Teknik Analisis}

Teknik Analisispenelitian ini didasarkan pada fakta yang terjadi di lapangan yang kemudian dilakukan kajian berupa eksistensi terhadap penerapan konsep nilai pembagian ruang pada level makro, khususnya yang terjadi di wilayah studi penelitian yaitu Kabupaten Badung Selatan. Jenis analisis yang digunakan adalah identifikasi dan deskriptif yang didukung pula dengan overlay peta penggunaan lahan. Data-data yang diperoleh melalui data spasial dan observasi lapangan tadi diolah dan disajikan menggunakan analisis spasial dan deskriptif kualitatif. Untuk data spasial diperoleh dari data sekunder instansi dan data spasial (peta-peta) lainnya yang diolah menggunakan alat Sistem Informasi Geografis (arcGIS) untuk mengetahui trend perubahan lahan pada wilayah kajian. Sedangkan data hasil kuesioner menggunakan analisis secara deskriptif kuantitatif. Dalam pengolahannya, data dari kuesioner tersebut disajikan dalam bentuk tabel, grafik maupun diagram yang kemudian diberi penjelasan secara deskriptif untuk menjelaskan gambaran tentang fenomena empiris di lapangan.

\section{GAMBARAN UMUM}

Wilayah Badung bagian selatan merupakan salah satu wilayah di konstelasi wilayah Kabupaten Badung yang mengalami perkembangan paling pesat bila dibandingkan dengan wilayah lainnya. Pesatnya perkembangan wilayah Badung bagian selatan ini sejalan dengan mulai berkembangnya sektor pariwisata di Propinsi Bali. Hal ini disebabkan karena bila dibandingkan dengan wilayah lainnya di Kabupaten Badung, wilayah Badung bagian selatan memiliki banyak potensi alam yang mudah untuk dikembangkan sebagai objek wisata, mengingat topografi wilayahnya yang landai dan bila dilihat berdasarkan batas wilayah administratif yang merupakan Samudera Indonesia, maka bentuk topografi wilayah Badung bagian selatan ini merupakan pantai berpasir putih sehingga merupakan wilayah pesisir yang tidak subur, dan sebagian besar wilayah ini merupakan wilayah yang datar. Potensi topografi yang demikianlah, 
mengakibatkan wilayah Kabupaten Badung bagian selatan menjadi obyek daya tarik wisatawan mancanegara, terutama dari negara-negara yang terdiri dari empat musim, dimana negara mereka sinaran matahari lebih singkat dibandingkan dengan negara beriklim tropis dengan dua musim seperti di Indonesia. Jumlah penduduk untuk wilayah Badung Selatan yang terdistribusi ke dalam tiga kecamatan yaitu Kecamatan Kuta Selatan memiliki jumlah penduduk 83.527 jiwa dengan kepadatan penduduk 826 jiwa perkm², kecamatan Kuta jumlah penduduk 40.315 jiwa dengan kepadatan 2.301 jiwa perkm²dan kecamatan Kuta Utara yang memiliki jumlah penduduk 68.422 jiwa dengan kepadatan penduduk 2.021 jiwa per km² (Kompilasi Data BPS, 2012). Adapun justifikasi dari penentuan wilayah Badung Selatan sebagai wilayah kajian adalah sebagai berikut:

- Wilayah Badung Selatan memiliki aktivitas yang lebih beragam, sehingga kebutuhan akan ruang memerlukan pengendalian.

- Wilayah Badung Selatan merupakan bagian wilayah Kabupaten Badung yang memiliki sarana dan prasarana yang memadai.

- Wilayah Badung Selatan merupakan pusat pengembangan kegiatan Pariwisata, sehingga banyak terdapat OTDW yang menjadi ikon pariwisata Bali.

\section{KAJIAN TEORI}

\section{Penataan Ruang}

Menurut Undang-Undang No. 26 Tahun 2007 Penataan Ruang adalah suatu sistem proses perencanaan tata ruang, pemanfaatan ruang, pengendalian pemanfaatan ruang. Pada dasarnya perencanaan tata ruang suatu wilayah merupakan upaya pengaturan dua elemen penting yaitu fisik wadah (the container) dan isi (the content), dan kedua elemen besar tersebut oleh Doxiadis dalam Mulyandari (2010) selanjutnya dapat dijabarkan menjadi elemen shell, network, nature, dan human resources. Shell merupakan ruang terbangun yang merupakan wujud fisik sekelompok bangunan; network adalah prasarana yang merupakan jaringan-jaringan yang mendukung aktivitas manusia; nature sendiri merupakan alam tempat manusia melakukan aktivitasnya sedangkan elemen yang terakhir adalah human resource merupakan sumber daya manusia yang memanfaatkan ruang. Pemaduserasian keempat elemen tersebut merupakan bentuk keberhasilan penataan ruang.

\section{Transformasi Nilai Budaya dari Masa ke Masa}

Budaya Bali merupakan suatu nilai berperilaku dalam kehidupan yang berdasarkan pada ajaran agama Hindu. Agama Hindu dan kebudayaan Bali merupakan dua hal yang berbeda, namun dalam kehidupan masyarakat Bali keduanya terkait secara sangat padu, secara saling melengkapi (Geriya dalam Salain, 2001). Williams dalam Kuntowijoyo, (2006) menyebutkan bahwa dalam sosiologi budaya kita menemukan adanya tiga komponen pokok, yaitu lembagalembaga budaya, isi budaya, dan efek budaya atau norma-norma, dengan kata lain, lembaga budaya menanyakan siapa yang menghasilkan produk budaya, siapa yang mengontrol, dan bagaimana kontrol itu dilakukan; isi budaya menanyakan apa yang dihasilkan atau simbolsimbol apa yang akan diusahakan; dan efek budaya menanyakan konsekuensi apa yang diharapkan dari proses budaya.

\section{Kajian terhadap Tata Ruang Makro Tradisional Bali}

Tata ruang makro wilayah desa dan kota di Propinsi Bali dipengaruhi oleh konsep-konsep nilai tradisional. Konsep nilai yang menjiwai unsur-unsur tersebut dijiwai oleh nilai-nilai Budaya yang diterjemahkan ke dalam wujud keruangan. Salah satu konsep nilai yang mendasari pembangunan wilayah di Propinsi Bali dilandasi oleh falsafah Tri Hita Karana, (Parhyangan, 
Pelemahan dan Pawongan). Pada dasarnya konsep nilai yang mendasari konteks keruangan (spasial) adalah Tri Hita Karana yang berfungsi untuk menjaga keseimbangan bhuana agung yaitu alam semesta dengan bhuana alit yaitu manusia itu sendiri. Suardana (2011) hirarki tata ruang atau kerap disebut juga Tri Mandala dimaksud tiga wilayah dalam tata letak bangunan. Ada wilayah untuk tempat bangunan suci bernilai utama (utama mandala), untuk tempat tinggal, bekerja hingga menyimpan barang (madya mandala). Tri Mandala merupakan hasil dari konsep psiko-kosmik dan menjadi aplikasi bentuk Tri Hita Karana. Tri Angga dan Tri Mandala merupakan konsep nilai yang berdasarkan pada jenis atau tipe aktivitasnya yaitu aktivitas yang bersifat sakral/utama, madya/tengah dan nista/profan. Dalam penerapan konsep Tri Mandala terkait dengan pembagian zone-zone aktivitasnya, yang berkaitan erat dengan konsep Rwa Bineda, dimana konsep ini merupakan penilaian berdasarkan dua hal yang bertentangan seperti misalnya 'Luan-Teben' (Hulu-Hilir), ‘Kaja-Kelod' (Utara-Selatan) dan juga 'Sakral-Profan' (Baik-Buruk).

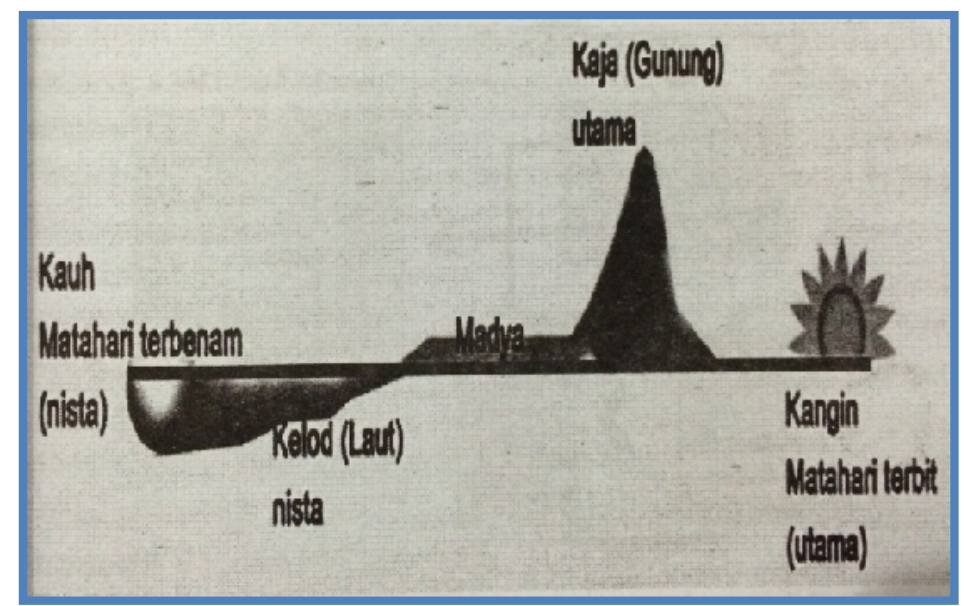

Sumber : Dwijendra, 2008

\section{GAMBAR 1}

KONSEP ARAH BERDASARKAN KAJA-KELOD DAN KANGIN-KAUH DI BALI

Berdasarkan konsepsi nilai tersebut tata ruang tradisional Bali dibentuk oleh 3 (tiga) sumbu yaitu sumbu alami bumi yaitu dibagi menjadi kaja yang diidentikkan dengan arah gunung sedangkan kelod yang merupakan laut, sumbu religius yang berkaitan dengan ritual keagamaan yang dimanifestasikan dengan arah terbitnya dan terbenamnya matahari, sumbu kosmos, dimana dunia ini dibagi menjadi alam atas (bhur loka) yang merupakan alam Sang Pencipta, alam tengah (bwah loka) yang merupakan alam para dewata dan swah loka sebagai alam para manusia. Aspek makro bila ditarik dalam suatu rencana tata ruang, maka perwujudannya terletak dalam penempatan kawasan atau wilayah zonasinya berdasarkan pola penempatan sebagai berikut :

1. Kawasan/zone hulu yang ditempatkan pada wilayah utara

Pada kawasan ini bila dilihat dari konsep nilai Rwa Bhineda adalah zone yang memiliki nilai utama atau Luan. Jenis aktivitas yang diperbolehkan pada zone ini lebih kepada aktivitas yang bersifat suci dan berhubungan dengan sang pencipta. Oleh karena itu dalam perletakannya pada umumnya untuk tempat persembahyangan atau memuja Ida Sang Hyang Widhi. Bila kita perhatikan pada perwujudan tata ruang Bali, sebelum terjadi perkembangan yang pesat dalam pemanfaatan lahan, zone ini merupakan tempat purapura Khayangan Jagat. Khayangan Jagat disini memiliki makna sebagai tempat persembahyangan yang diusung oleh seluruh umat Hindu di Bali. Ciri yang mendasari tempat ini sebagai zone hulu adalah letak topografinya yang lebih tinggi. Memiliki wilayah 
topografi yang cenderung lebih tinggi kawasan ini memiliki potensi sebagai kawasan konservasi hutan lindung dan juga wilayah resapan air sehingga sebagai penyimpanan sumber daya air.

2. Kawasan/zone tengah/madya

Zone atau kawasan tengah dalam rencana tata ruang merupakan suatu zone yang merupakan tempat berlangsungnya aktivitas yang berkaitan dengan hubungan antara manusia dan manusia sebagai makhluk sosial. Maksudya disini merupakan zone untuk permukiman dan pembangunan infrastuktur sehingga menjadi pusat beraktifitas untuk kelangsungan hidup. Zone ini memiliki nilai yang lebih rendah dari zona utama namun lebih tinggi daripada zone nista.

3. Kawasan/zone profan/teben

Pada kawasan profan atau bila berdasarkan konsep Rwa Bineda, zone ini memiliki nilai nista atau buruk, dan berada pada wilayah teben (Selatan). Berdasarkan nilai pada zone ini yang bersifat nista atau buruk maka zone ini lebih diperuntukkan untuk aktivitas yang bersifat kotor seperti misalnya pembuangan limbah, kuburan. Topografi pada kawasan ini pada umumnya paling rendah daripada zone-zone yang lainnya. Zone ini pada umumnya merupakan kawasan yang berupa pantai, karena dalam tradisi masyarakat Hindu di Bali memiliki fungsi untuk mensucikan yang kotor.

Pembagian zone atau kawasan tersebut menjadi dasar yang diadopsi oleh peraturan daerah di Propinsi Bali dalam kegiatan penataan ruang. Konsepsi nilai ini merupakan konsep tata ruang secara makro ke arah horizontal sistem keruangan di Propinsi Bali.

\section{ANALISIS}

\section{Perbandingan Pemanfaatan Ruang di Wilayah Selatan Kabupaten Badung}

Analisis perubahan penggunaan lahan dalam penelitian ini berfokus pada wilayah selatan Kabupaten Badung. Tujuan dari dilakukannya analisis ini adalah untuk melihat trend perubahan pemanfaatan ruang, sehingga dari analisis tersebut dapat dilihat bagaimana eksistensi dari penerapan konsep nilai pembagian ruang pada level makro. Pemilihan wilayah penelitian ini dikarenakan wilayah selatan Kabupaten Badung merupakan wilayah yang memiliki kawasan wisata dengan perkembangan yang sangat pesat dalam kurun waktu 7 tahun. Berikut merupakan tabel yang menjelaskan perkembangan penggunaan lahan yang terjadi dengan membandingkan data Penataan Guna Lahan dari Badan Pertanahan Kabupaten Badung tahun 2003 sampai dengan 2010. Selanjutnya untuk mengetahui besar perkembangan masing-masing pemanfaatan ruang (penggunaan lahan) dapat dilihat pada tabel dan grafik dibawah ini

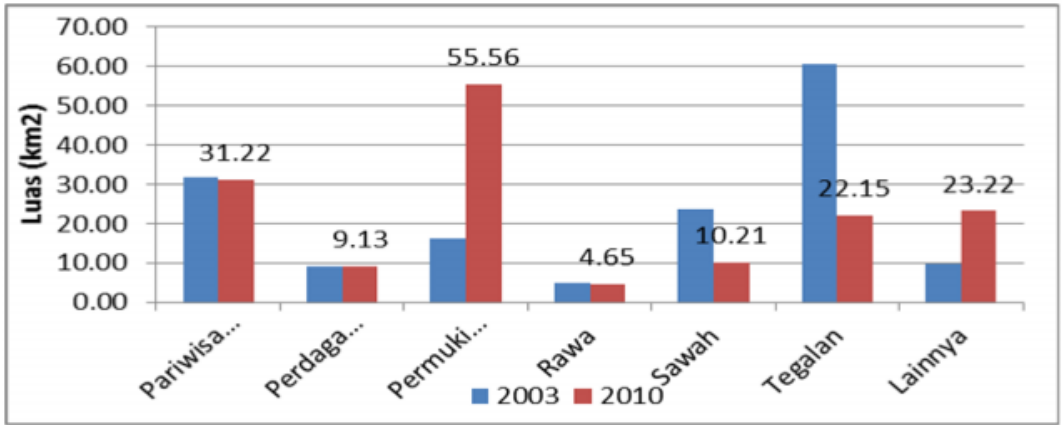

Sumber : Hasil Analisis Penulis, 2014

GAMBAR 2

PERBANDINGAN PEMANFAATAN RUANG DI WILAYAH BADUNG SELATAN 
Peningkatan jumlah pemanfaatan ruang yang paling signifikant adalah untuk permukiman yang pada tahun 2003 sebesar 11\% bertambah menjadi 36\%, dan untuk tegalan mengalami penurunan yang tinggi juga yaitu dari $39 \%$ menjadi $14 \%$, fenomena ini menandakan bahwa alih fungsi lahan yang terjadi di wilayah Badung Selatan sangat tinggi.

\section{Perubahan Pemanfaatn Ruang (Penggunaan Lahan) Pada Kondisi Eksisting Dengan Konsep Nilai Pembagian Pada Level Makro}

Konsep local genius Tradisional Bali dalam substansi tata ruang merupakan suatu upaya untuk menjaga keberlanjutan lingkungan alam dan lingkungan sebagai wadah manusia untuk hidup. Berdasarkan hasil wawancara dengan Ibu Gusti Ayu Suartika (2014) yang merupakan seorang akademisi yang telah banyak melakukan penelitian terkait dengan substansi nilai tradisional Bali dalam kebijakan tata ruang, konsep pembagian tata ruang makro berdasarkan konsep Tradisional Bali berdasarkan pada yaitu berdasarkan konsep Rwa Bineda yang artinya dua hal yang berlawanan atau berbeda. Konsep ini juga menjadi nilai penentu dalam penerapan konsep Tri Mandala yang merupakan nilai pembagian ruang pada level makro secara Horizontal. Dalam konsep Rwa Bineda yang menjadi dasar nilai tradisional Bali, tersebut masing-masing nilai memiliki wilayah yang bersifat madya (tengah). Makna dari pembagian ruang ini adalah agar pada setiap kawasan/zona memiliki peruntukkan tertentu yang berdasarkan konsep Tri Hita Karana sehingga keseimbangan setiap zona/kawasan dapat menciptakan keseimbangan alam /lingkungan yang berkelanjutan.

Penerapan konsep nilai untuk wilayah Selatan Kabupaten Badung lebih relevan menggunakan istilah zona kawasan yang berdasarkan konsep "Luan dan Teben" yang pemanfaatan ruang pada setiap zona tersebut juga berdasarkan peruntukkan untuk jenis kegiatan yang pada dasarnya sama dengan konsep nilai Tri Mandala, hanya saja untuk melihat konsep Tri Mandala dilihat penerapannya pada kawasan Desa Adat atau Desa Pakraman, hal ini berkaitan dengan adanya perbedaan penerapan batas wilayah antara wilayah administratif yang dibuat oleh Negara dan wilayah adat yang merupakan ketentuan secara turun temurun. (Wawancara dengan Gusti Ayu Made Suartika, 2014 akademisi yang telah banyak melakukan penelitian Tentang Substansi Kebijakan Tata Ruang di Bali Berdasarkan Nilai Tradisional Bali). Maka dengan demikian bila dikaitkan dengan konsepsi nilai tata ruang tradisional Bali secara makro dengan berpedoman pada konsep sumbu alami bumi yaitu dibagi menjadi kaja yang diidentikkan dengan arah gunung sedangkan kelod yang merupakan laut dan sumbu religius yang berkaitan dengan ritual keagamaan yang dimanifestasikan dengan arah terbitnya dan terbenamnya matahari. Berdasarkan peta eksisting pemanfaatan ruang, maka dapat dilihat eksistensi konsep nilai tersebut pada setiap zona atau kawasan.

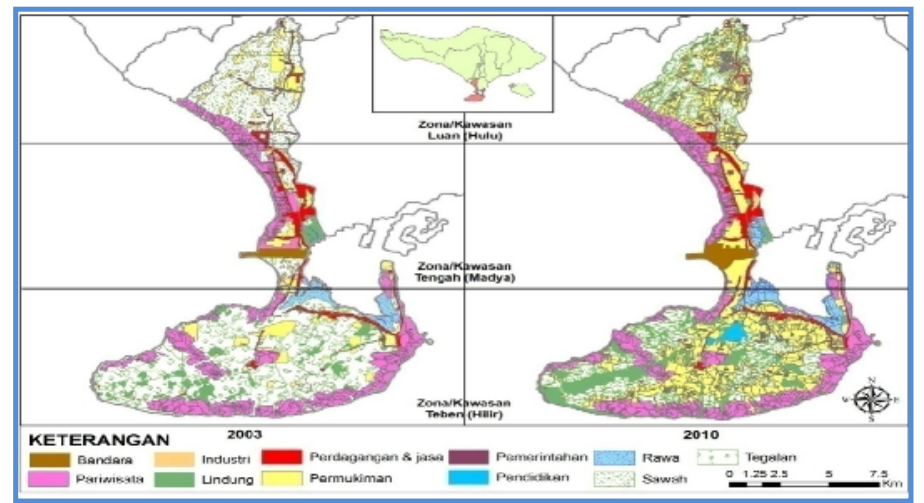

Sumber : Hasil Analisis Penulis, 2014

GAMBAR 3

PERBANDINGAN PEMANFAATAN RUANG DI WILAYAH BADUNG SELATAN 
Konsep nilai pembagian ruang berdasarkan gambar tersebut diatas, menghasilkan tiga zona/kawasan dengan jenis dan peruntukkan khusus yang bertujuan untuk menjaga keseimbangan lingkungan antara di hulu dan di hilir. Namun dalam perkembangan dewasa ini jenis peruntukkan tersebut tidak lagi bersifat khusus, bahkan sekarang telah bercampur serta beragam, dan responden berpendapat paling banyak terjadi perbedaan antara konsep nilai dan penerapannya terjadi di zona/kawasan Teben (Hilir) atau Kelod (Selatan) yang identik dengan wilayah pantai, sedangkan zona/ kawasan yang menurut pendapat responden paling sedikit terjadi ketidaksesuaian adalah zona tengah, hal ini disebabkan karena peruntukkan zona tengah secara konsepsi merupakan untuk jenis kegiatan yang beragam khususnya yang mendukung kehidupan manusia dalam beraktivitas demi keberlanjutannya. Pendapat responden terkait dengan zona/kawasan yang dalam penerapannya terjadi ketidaksesuaian, digambarkan dalam diagram sebagai berikut :

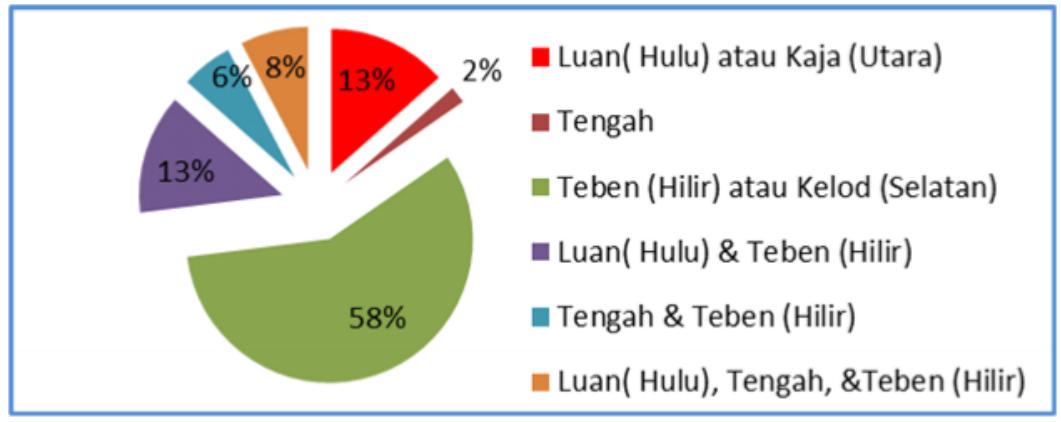

Sumber : Hasil Analisis Penulis, 2014

GAMBAR 4

KONSEP PEMBAGIAN RUANG YANG BANYAK TERJADI KETIDAKSESUAIAN

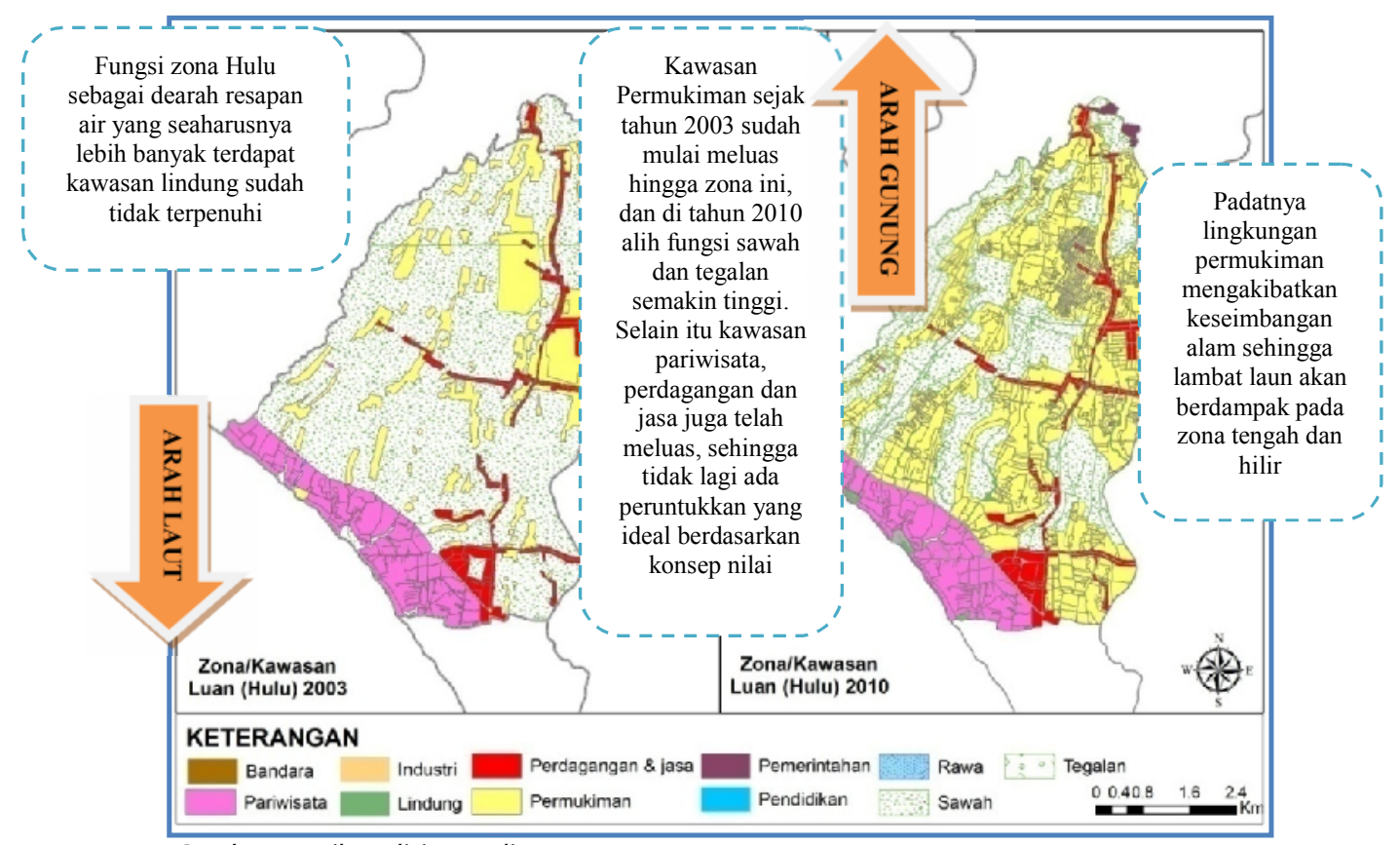

Sumber : Hasil Analisis Penulis, 2014

GAMBAR 5

PETA PEMANFAATAN RUANG PADA ZONA/KAWASAN LUAN (HULU) 
Zona/kawasan Luan (Hulu) identik sebagai kawasan yang peruntukkannya untuk jenis kegiatan yang bersifat sakral (fungsi Parahyangan) dimana ciri khusus zona ini adalah adanya Pura dan Hutan. Pada Perkembangannya zona atau kawasan utara yang merupakan daerah Luan (Hulu) secara makro untuk wilayah Badung Selatan tidak terdapat lagi peruntukkan yang khusus sesuai dengan konsep nilai tradisional Bali. Zona utara di wilayah Badung Selatan dalam perkembangannya terdapat peruntukkan yang beragam dengan keberadaan sawah dan hutan yang lebih banyak dibandingkan zona tengah dan hilir untuk menjaga keseimbangan alam. Kondisi ini tidak sesuai karena pemanfaatan ruang permukiman memiliki proporsi $47 \%$, perdagangan dan jasa $6 \%$, dan pariwisata $11 \%$, sedangkan untuk kawasan lindung hanya $1 \%$, sawah $29 \%$ dan tegalan $0 \%$. Maka jika dibandingkan dengan konsep nilai sebaiknya persentase kawasan lindung, sawah dan tegalan memiliki porsi lebih besar dari total pemanfaatan ruang.

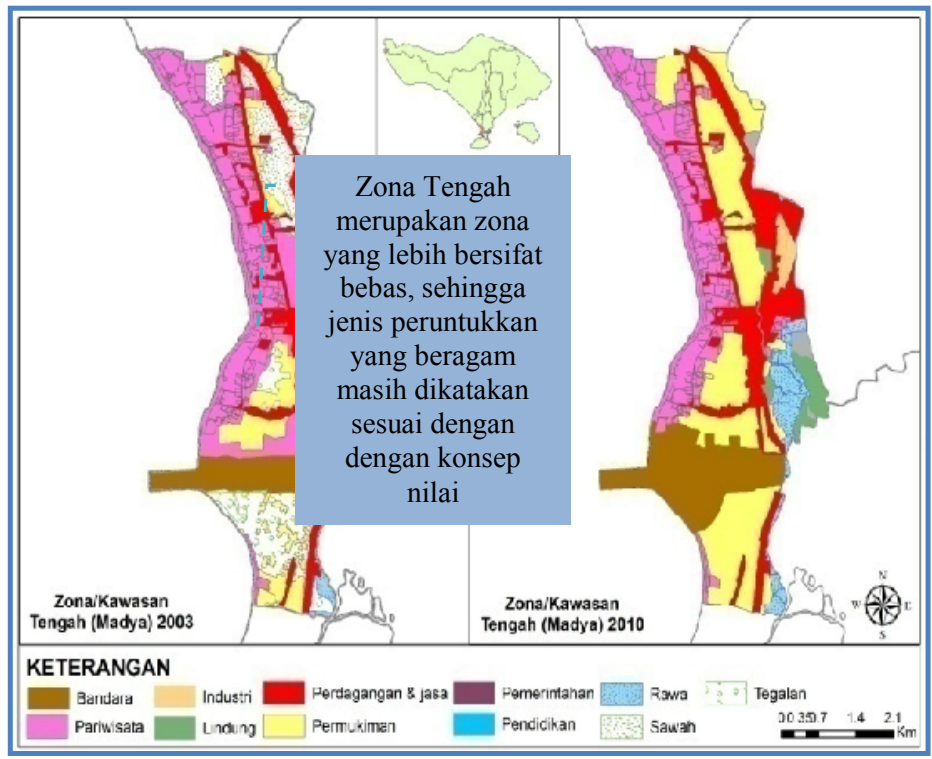

Sumber : Hasil Analisis Penulis, 2014

GAMBAR 6

PETA PEMANFAATAN RUANG PADA ZONA/KAWASAN TENGAH

Kawasan Tengah merupakan perwujudan ruang untuk menjalankan aktivitas manusia yang bila dikaitkan dengan konsep Tri Hita Karana sebagai perwujudan fungsi Pawongan. Pada zona ini segala bentuk kegiatan yang bertujuan untuk keberlanjutan masyarakat seperti kawasan permukiman dan falisitas penunjang berada pada zona ini. Serta perkembangan sektor pariwisata, perdagangan dan jasa berkembang pesat.Kondisi ini sesuai karena pemanfaatan ruang bersifat bebas tidak ada pengaturan khusus untuk 1 (satu) jenis peruntukkan.

Zona/Kawasan Teben (Hilir) atau Kelod (Selatan) adalah berfungsi sebagai tempat melakuka pembuangan, yang bersifat nista/kotor. Zona/Kawasan Teben (Hilir) atau Kelod (Selatan), telah mengalami perkembangan yang terjadi seperti pada zona hulu dan juga zona tengah, permukiman yang telah berkembang hingga ke zona ini. Bahkan perkembangan pembangunan di Bali atas dasar pariwisata berkembang di wilayah dan zona ini. Ditambah lagi kebijakan pemerintah yang membangun sarana akomodasi pariwisata di wilayah ini, semakin menyebabkan zona selatan sebagai barometer perkembagan pembangunan di wilayah Badung. Topografi wilayah hilir yang sebagian besar berupa pantai semain menyebabkan menjamurnya perdagangan dan jasa serta sarana akomodasi pariwisa. Kondisi ini tidak sesuai 
karenapemanfaatan ruang permukiman menempati $32 \%$ dari total pemanfaatan ruang, perdagangan dan jasa $3 \%$ dan pariwisata $23 \%$.

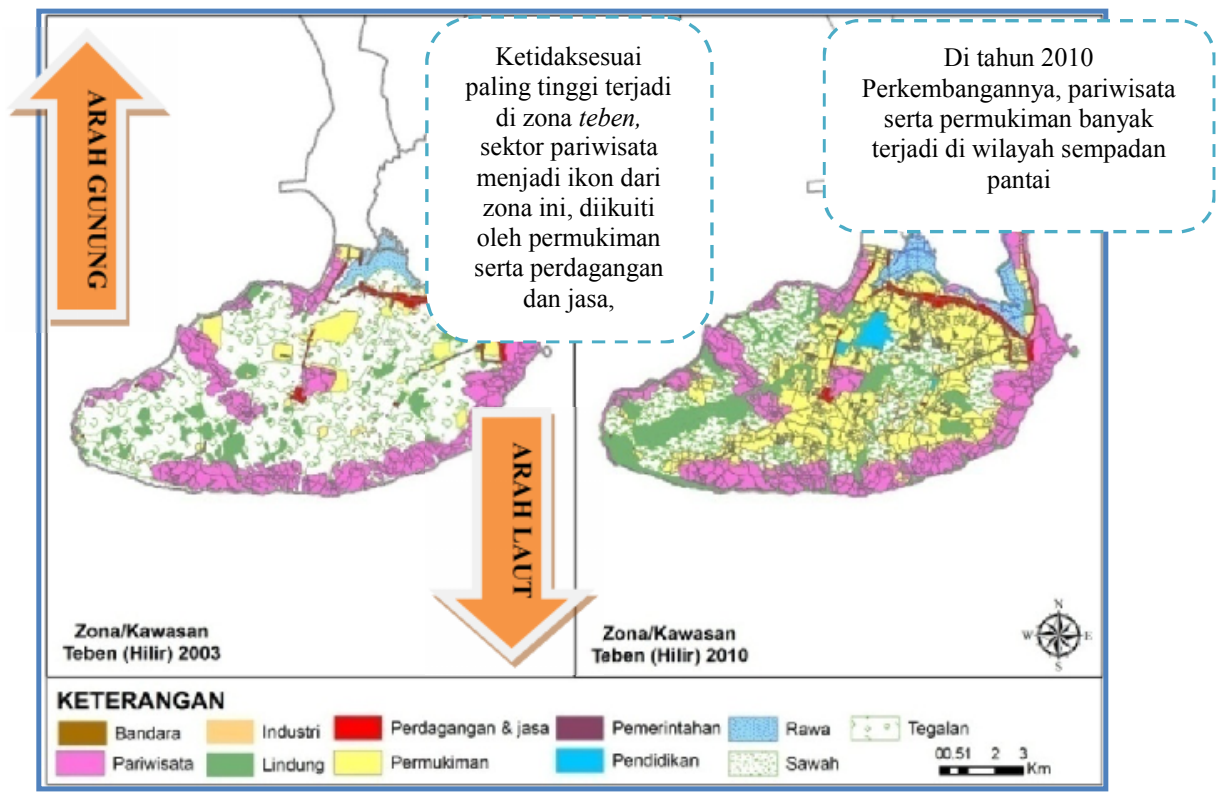

Sumber : Hasil Analisis Penulis, 2014

GAMBAR 7

PETA PEMANFAATAN RUANG PADA ZONA/KAWASAN TEBEN (HILIR)

Zona/Kawasan Teben (Hilir) atau Kelod (Selatan) adalah berfungsi sebagai tempat melakuka pembuangan, yang bersifat nista/kotor. Zona/Kawasan Teben (Hilir) atau Kelod (Selatan), telah mengalami perkembangan yang terjadi seperti pada zona hulu dan juga zona tengah, permukiman yang telah berkembang hingga ke zona ini. Bahkan perkembangan pembangunan di Bali atas dasar pariwisata berkembang di wilayah dan zona ini. Ditambah lagi kebijakan pemerintah yang membangun sarana akomodasi pariwisata di wilayah ini, semakin menyebabkan zona selatan sebagai baromater perkembagan pembangunan di wilayah Badung. Topografi wilayah hilir yang sebagian besar berupa pantai semain menyebabkan menjamurnya perdagangan dan jasa serta sarana akomodasi pariwisa. Kondisi ini tidak sesuai karenapemanfaatan ruang permukiman menempati $32 \%$ dari total pemanfaatan ruang, perdagangan dan jasa $3 \%$ dan pariwisata $23 \%$.

\section{Penyebab Terjadinya Pergeseran Local Genius dalam Penerapan Konsep Nilai Pembagian Ruang Makro}

Pulau Bali adalah pulau yang memiliki keterbatasan sumber daya alam, khususnya hasil tambang dan juga lahan pertanian yang terbatas, namun di satu sisi diberikan kekayaan sumber daya budaya yang memiliki keunikan dan kekhasan sehingga menarik minat bangsa lain untuk berkunjung dan menikmatinya. Kekayaan sumber daya budaya inilah yang dijadikan sebagai komoditi pariwisata. Selama tiga dekade terakhir, pemerintah pusat telah mengidentifikasi pariwisata sebagai sektor utama bagi pembangunan perekonomian Bali, sehingga Pemerintah melakukan upaya yang diperlukan untuk mendukung industri pariwisata. Investor disambut untuk berinvestasi dalam mendukung pembangunan infrastruktur, dan juga pembangunan fasilitas pariwisata dan dengan dalih demi meningkatkan perekonomian masyarakat dan penyediaan lapanngan pekerjaan, mengakibatkan terjadinya konversi lahan semakin tinggi, yang tentu saja berdampak pada keberlanjutan lingkungan alam di Bali dan 
juga keberlanjutan nilai local genius yang berkembang di Bali. Terjadinya keharmonisan dengan alam sesuai ajaran agama HinduBerikut ini alasan para responden terkait dengan mengapa konsep nilai pembagian ruang pada level makro tersebut perlu dipertahankan yang disajikan dalam gambar sebagai berikut :
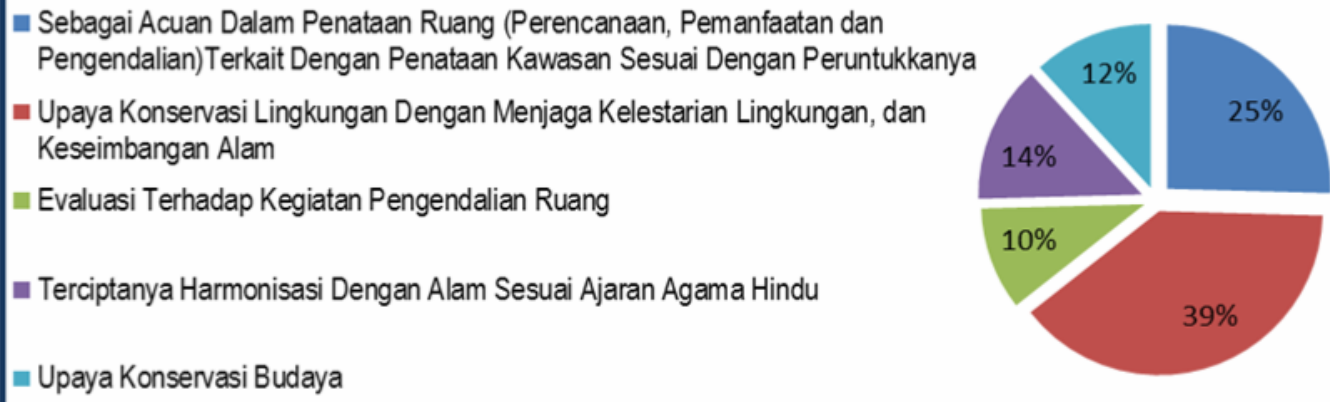

Sumber : Hasil Analisis Penulis, 2014

\section{GAMBAR 9}

\section{ALASAN MEMPERTAHANKAN PENERAPAN KONSEP NILAI PEMBAGIAN RUANGPADA LEVEL MAKRO}

Penerapan konsep ini di masa sekarang dan kedepannya merupakan bukan hal yang mudah, sehingga sebesar $96 \%$ responden berpendapat bahwa terdapat kendala-kendala dalam upaya penerapan konsep pembagian ruang pada level makro. Kendala tersebut terkait dengan isu keterbatasan lahan sedangkan pertumbuhan penduduk yang sulit dibendung serta ditambah lagi akibat tingginya investasi sebagai dampak dari majunya sektor pariwisata. Responden yang berpendapat bahwa tidak terdapat kendala/permasalahan dalam penerapan konsep nilai pembagian ruang pada level makro adalah dikarenakan pemerintah, masyarakat dan stakeholder lainnya dapat bekerja dengan berkordinasi dengan baik maka permasalahan yang dihadapi dapat diminimalisir. Terdapatnya kendala yang sedemikian kompleksnya menyebabkan, setiap tahun eksistensi dari konsep nilai pembagian ruang pada level makro ini mulai mengalami pergeseran, dimana pada setiap zona tidak terdapat lagi kekhususan jenis peruntukkan. Hal ini disebabkan karena beberapa faktor-faktor penyebab terjadinya ketidaksesuaian tersebut. Faktor-faktor penyebab terjadinya ketidaksesuain tersebut digambarkan pada diagram sebagai berikut :

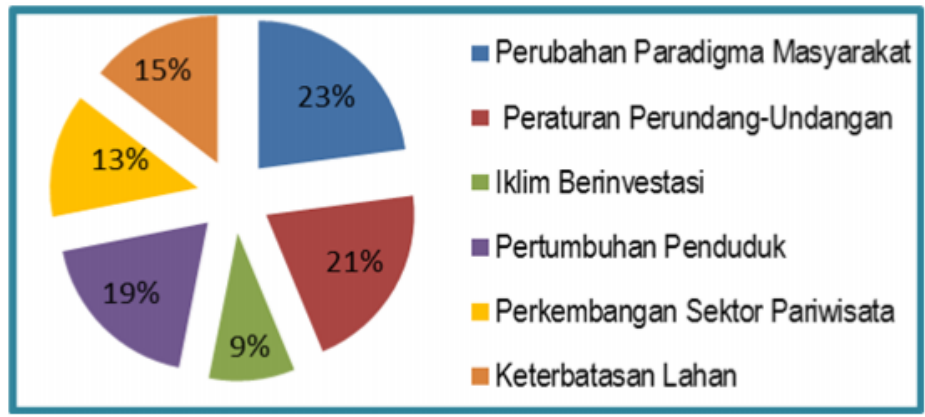

Sumber : Hasil Analisis Penulis, 2014

\section{GAMBAR 10 \\ FAKTOR YANG MEMPENGARUHI KETIDAKSESUAIAN PENERAPAN KONSEP NILAI DENGAN KONDISI LAPANGAN}




\section{Temuan Studi}

Wilayah Selatan dari Kabupaten Badung memiliki permasalahan alih fungsi lahan. Permasalahan alih fungsi lahan tentu saja berpengaruh terhadap penerapan nilai-nilai budaya yang terkait dengan kebijakan penataan ruang di wilayah Bali. Konsep nilai subtansi budaya dalam kebijakan penataan ruang, mengatur mengenai peruntukkan untuk jenis kegiatan tertentu pada suatu kawasan. Fungsi dari nilai tradisional pembagian ruang Bali pada level makro ini bertujuan untuk menjaga keseimbangan alam. Jika disandingkan penerapan nilai tradisional ini sesuai dengan penerapan konsep pembangunan yang berkelanjutan. Konsep pembangunan berkelanjutan ini memiliki tujuan yang sama dengan nilai tradisional pembagian ruang Bali pada level makro yaitu pemanfaatan ruang sebagai wadah aktivitas manusia, namun disisi lain manusia harus lebih bijaksana dalam pemanfaatannya agar tidak merusak lingkungan. Apabila dikaitkan antara konsep pembangunan berkelanjutan dan upaya penerapan substansi budaya dalam kebijakan panataan ruang di Bali dengan berdasarkan pada pembagian ruang pada level makro, maka hal tersebut sejalan demi terciptanya konservasi lingkungan. Namun ditengah perkembangan pembangunan yang pesat khususnya di wilayah Selatan Kabupaten Badung, mengakibatkan terjadinya pergeseran terhadap penerapan pembagian ruang Bali pada level makro seperti yaitu berubahnya kawasan nista mandala menjadi peruntukkan yang lebih bernilai ekonomis menjadi kawasan pariwisata, hotel, villa, permukiman, dan perdagangan, tingginya investasi wilayah pantai sehinga terjadi kesulitan penerapan arahan kebijakan tentang jarak sempadan pantai pada kawasan-kawasan yang telah terbangun, dan hal tersebut berdampak pada semakin tingginya tingkat abrasi pantai, tingginya alih fungsi lahan pertanian di Kecamatan Kuta Utara yang merupakasebagai akibat dari percepatan pertumbuhan kawasan permukiman perkotaan, pelanggaran di kawasan utama mandala dengan melihat pada kondisi eksisting banyak terjadi pelanggaran "bhisama kesucian pura" dan pembangunan tidak merata khususnya di wilayah selatanKabupaten Badung.

Situasi dan kondisi tersebut diatas merupakan fakta yang terjadi di wilayah eksisting, sehingga menimbulkan ketidakseimbangan sebagai akibat dari mulai memudarnya penerapan konsepkonsep keraifan lokal seperti Tri Hita Karana, Tri Mandala, Bhisama Kesucian Pura, luan/teben/kaja/kelod dan lainnya dalam pengembangan strukur dan pola ruang wilayah secara lebih nyata dan tegas. Ketidakkonsistenan ini tentu saja menimbulkan dampak pada permasalahan isu lingkungan khususnya wilayah nista/teben/hilir yang merupakan pantai dengan kerentanan tinggi terkena potensi gelombang tinggi (tsunami) dan gempa sehingga membutuhkan penerapan konsep-konsep mitigasi dan adaptasi penataan kawasan pesisir.

Penerapan nilai pembagian ruang Bali pada level makrodengan melihat pada relevansinya pada dua jenis pembagian wilayah dapat dikatakan telah terjadi ketidaktegasan dan pergeseran. Hal tersebut tentu saja akan menggannggu keseimbangan alam yang menjadi manfaat utama dari penerapan nilai-nilai kearifan lokal. Nilai-nilai kearifan lokal ini merupakan landasan yang menjadi dasar dalam aktivitas pemanfaatan ruang demi keberlanjutan alam dan juga manusia yang hidup beraktivitas didalamnya. 


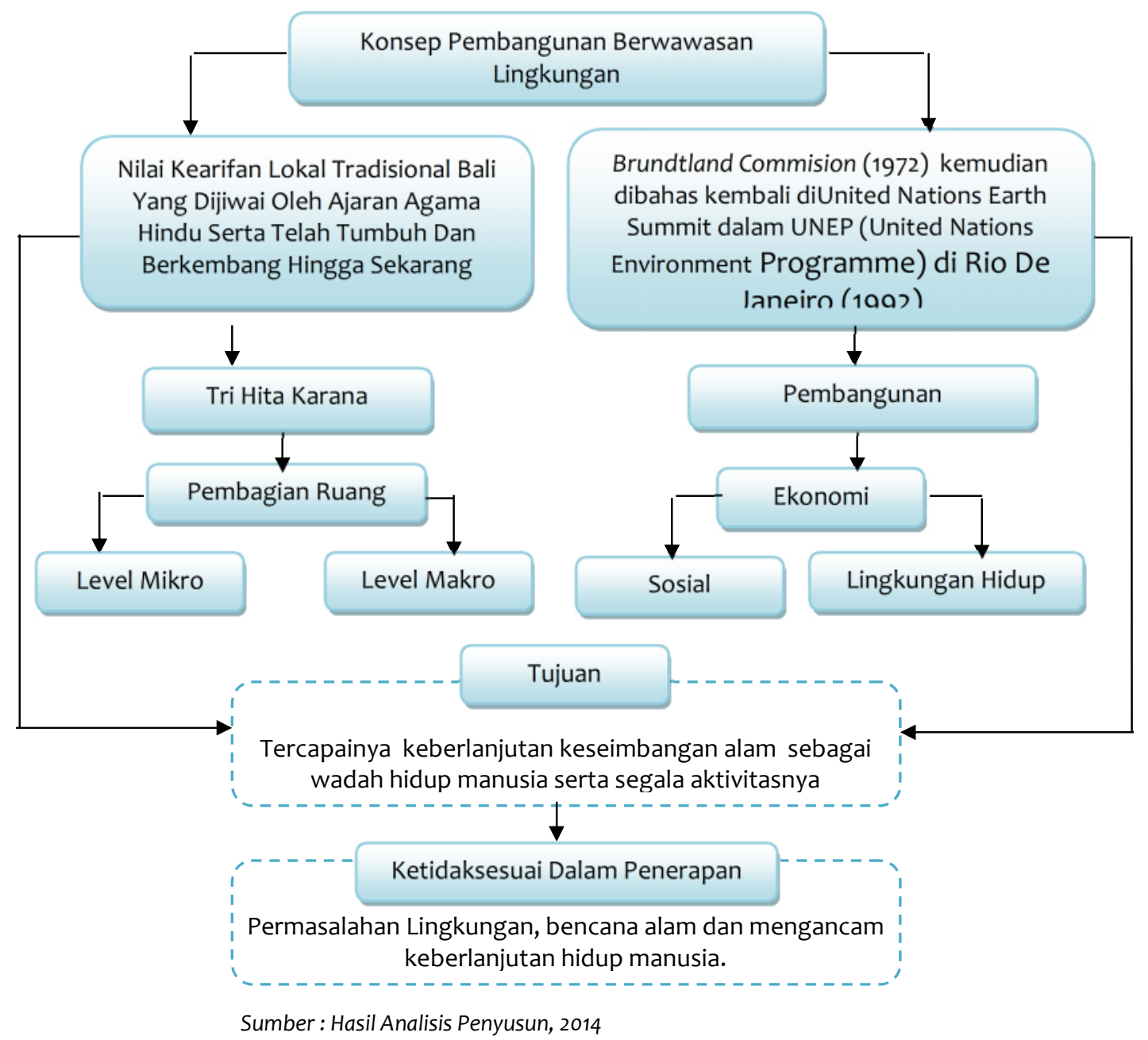

\section{GAMBAR 12 \\ KONSEP PENERAPAN PEMBANGUNAN BERWAWASAN LINGKUNGAN MENURUT PANDANGAN KONSEP TRADISIONAL BALI DAN MODERN}

\section{KESIMPULAN}

Eksistensi dari kearifan lokal (local genius) konsep nilai pembagian ruang pada level makro telah mengalami pergeseran dan eksistensi dari nilai tersebut telah berkurang. Pergeseran yang terjadi adalah tidak dipenuhinya lagi peruntukkan untuk jenis kegiatan pada masingmasing zona /kawasan, pada setiap kawasan dan zona berdasarkan hasil overlay peta pemanfaan ruang terdapat beragam jenis aktivitas, baik itu yang bersifat suci atau sakral maupun aktivitas pariwisata ataupun perdagangan dan jasa, dan pergeseran yang kedua adalah terjadi perubahan pada luasan zona atau kawasan terutama kawasan hulu (luan/kaja), atau utama mandala dan juga hilir (teben/kelod), atau nista mandala, namun pada hakekatnya esensisecara jiwa dari konsep nilailocal geniustersebut tidak terdapat perubahan, tetap tumbuh dan dipertahankan oleh masyarakat. Sebagai contoh pada kawasan untuk tempat suci yang bersifat sakral selalu berada di wilayah hulu (luan/kaja), tidak berubah ke arah hilir atau teben/kelod yang artinya tetap berada di wilayah utama mandala, hanya saja perkembangannya 
pada masa sekarang disekitar wilayah suci tersebut telah berkembang juga pola aktivitas yang lain. Untuk wilayah nista apabila dilihat berdasarkan konsep wilayah nista mandala diperuntukkan untuk aktivitas yang bersifat kotor seperti misalnya pembuangan limbah, kuburan atau kegiatan lain yang lebih berfungsi sebagai pembersihan dari segala kegiatan yang dilakukan pada wilayah madya mandala, akan tetapi belakangan ini perkembangan wilayah nista telah berubah peruntukkannya menjadi wilayah yang paling diminati oleh kalangan investor sehingga kegiatan-kegiatan yang seharusnya dilaksanakan di wilayah madya mandala sekarang telah meluas ke wilayah nista sehingga dampaknya akan mempengaruhi keseimbangan alam. Berkurangnya eksistensi dalam penerapan konsep nilai tersebut yang berakibat menimbulkan pergeseran disebabkan oleh berbagai faktor yang dapat berpengaruh pada perkembangan pemanfaatan ruang di dalam penerapan kegiatan penataan ruang di wilayah Badung Selatan yang semakin tidak terkendali.

\section{DAFTAR PUSTAKA}

Badung dalam Angka Tahun 2013. Badan Pusat Statistik Kabupaten Badung, 2013.

Kuntowijoyo. 2006. Budaya dan Masyarakat. Yogyakarta: Tiara Wacana.

Salain, Putu Rumawan et al. 2001. Strategi Pembangunan Kota Denpasar yang Berwawasan Budaya Sebuah Bunga Ramoai Lanjutan dalam Perspektif Sektoral. Bappeda Kota Denpasar.

Sugiyono. 2008. Metode Penelitian Kuantitatif, Kualitatif, dan R\&D. Bandung: Alfabeta. Undang-Undang No 26 Tahun 2007 tentang Penataan Ruang.

Peraturan Daerah Propinsi Bali Nomor 16 Tahun 2009 tentang Rencana Tata Ruang Wilayah Propinsi Bali Tahun 2009 - 2029. 